\title{
Compressibility and swelling of an overconsolidated highly plastic Paleogene clay
}

\author{
Rocchi, Irene; Di Remigio, Giorgia; Grønbech, Gitte Lyng; Zania, Varvara
}

Publication date:

2018

Document Version

Peer reviewed version

Link back to DTU Orbit

Citation (APA):

Rocchi, I., Di Remigio, G., Grønbech, G. L., \& Zania, V. (2018). Compressibility and swelling of an overconsolidated highly plastic Paleogene clay. Paper presented at micro to MACRO Mathematical Modelling in Soil Mechanics 2018, Reggio Calabria, Italy.

\section{General rights}

Copyright and moral rights for the publications made accessible in the public portal are retained by the authors and/or other copyright owners and it is a condition of accessing publications that users recognise and abide by the legal requirements associated with these rights.

- Users may download and print one copy of any publication from the public portal for the purpose of private study or research.

- You may not further distribute the material or use it for any profit-making activity or commercial gain

- You may freely distribute the URL identifying the publication in the public portal

If you believe that this document breaches copyright please contact us providing details, and we will remove access to the work immediately and investigate your claim. 


\title{
Compressibility and swelling of an overconsolidated highly plastic Paleogene clay
}

\author{
Irene Rocchi $^{1}$, Giorgia Di Remigio ${ }^{1}$, Gitte Lyng Grønbech ${ }^{1}$, Varvara Zania ${ }^{1}$
}

${ }^{1}$ Department of Civil Engineering, Technical University of Denmark, DTU.

\begin{abstract}
High plasticity clays of Paleogene origin are frequently met in northern Europe, typically overconsolidated as a result of overburden pressure during the ice age. Moreover, the advancing and melting of the glaciers has affected their macrostructure, and clays are found pre sheared in some zones, while deeper layers are intact. Compressibility and swelling dominate the mechanical behavior, with considerable impacts in the design of modern infrastructure. This study focuses on the Paleogene Røsnæs Clay found between southern Denmark and northern Germany, which is characterized by high plasticity attributed to the smectite mineral content (20 - $50 \%$ ). Incremental loading one-dimensional compression tests were carried out on undisturbed Folded and Intact Røsnæs Clay using different salinity levels of the water in the oedometric cell and comparing the behavior with that of reconstituted samples having similar mineralogical composition to assess the influence of structure. Furthermore, the stress dependency of stiffness and creep rate was analyzed during unloading-reloading cycles achieving progressively higher stress levels.
\end{abstract}

Key words: swelling sensitivity, pore water composition, salinity, deionized water, high plasticity clay, secondary compression index

\section{Introduction}

Paleogene clays are frequently met during the geotechnical investigation for infrastructures in Denmark and other cities in northern Europe. According to King [1], the North Sea sedimentary basin resulted from regional tectonics during the late Paleocene. This originally included a large part of northern and northeastern Europe, England and Scotland, resulting in some common features in the clays across these areas. However, subsequent regional geological events, differentiated the clays in each geographical area.

Røsnæs Clay is a Paleogene clay found in the Fehmarn Belt area, located between the southern part of Denmark and the northwestern part of Germany, where a future subsea immersed tunnel is planned. Similarly to other well documented 
Paleogene clays, such as the London clay, Røsnæs Clay is very stiff and fissured, showing clear signs of slickensides, while on the other hand it is highly plastic. Additionally it has undergone consolidation and extensive shearing under the action of glaciers which resulted to the shallower part of this formation being characterized as "folded". Røsnæs Clay remains as of today exposed to marine environment at the sample location (Fig.1).

This paper presents an initial set of results investigating the behavior of Intact and Folded Røsnæs Clay in one-dimensional compression and swelling, with respect to salinity of the pore fluid. The comparison with reconstituted samples provides the opportunity to study the influence of the glaciers action.

(a)

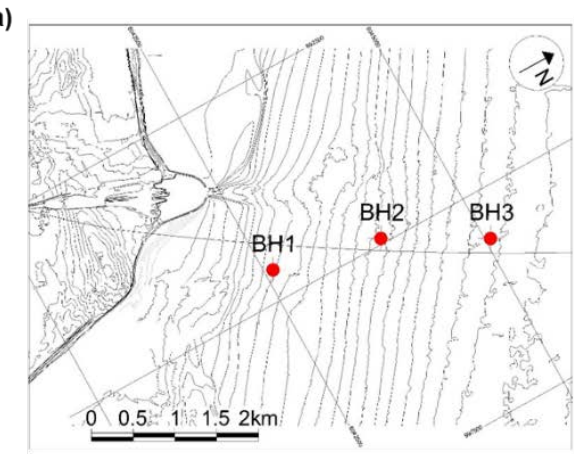

(b)

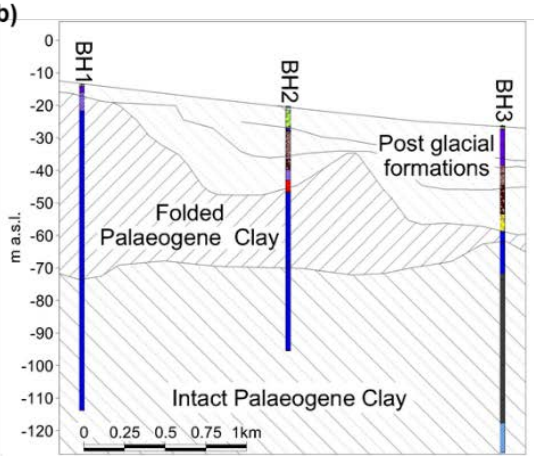

Fig. 1: Site location. (a) plan view and (b) simplified geological cross section.

\section{Material tested}

At the sample location (Fig.1a), the samples tested were overlaid by post- and late-glacial sediments and floe of Røsnæs Clay. The Folded Røsnæs Clay is 3m-52 $\mathrm{m}$ thick and the Intact Røsnæs Clay below reaches more than $100 \mathrm{~m}$ depth (Fig.1b). The undisturbed samples used were retrieved between 53.5 - $55.5 \mathrm{~m}$ depth from the ground level (Fig.1b), corresponding to both Folded and Intact Røsnæs clay of approximately 52 million years age.

The mineralogy composition of the Røsnæs clay, as determined by means of XRD analyses, varies considerably with depth in Fig.2, but generally the smectite content is 15 - $55 \%$ of the total dry weight, illite 30 - $55 \%$ and kaolinite $10-35 \%$. The mineral composition along the $\mathrm{BHs}$ from which the samples were taken is shown with continuous lines and at the depth of interest (53.5 - $55.5 \mathrm{~m}$ ) a considerable scatter is observed. For the Folded Røsnæs Clay a sample adjacent to that tested consisted of smectite (17 - $18 \%$ ), illite ( $53-54 \%$ ) and kaolinite (29 - $30 \%)$ including chlorite, which is the same as for the reconstituted samples. Unfortunately 
no XRD analysis was available in close proximity of the Intact Røsnæs Clay sample tested, but based on the plasticity index $\mathrm{I}_{\mathrm{p}}$ showed in Table 1, the mineralogical composition seems to resemble that of the Folded Røsnæs Clay. However, the results show that significant variability is encountered even within a single sample, as the plasticity index ranges between $87.1 \%$ and $101.8 \%$.

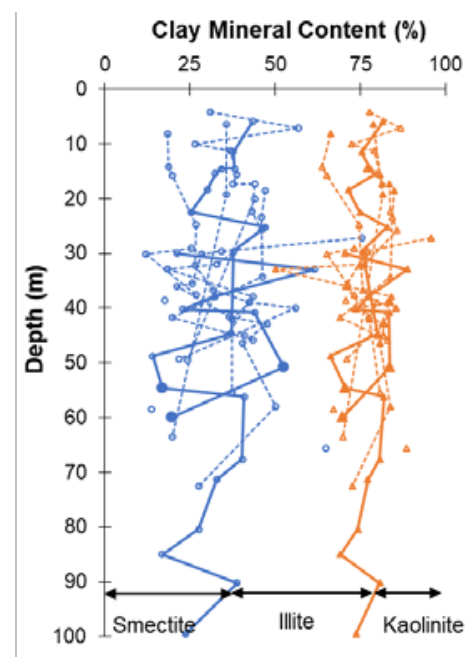

Fig. 2: Mineralogical composition of the clay fraction across the Fehmarn Belt tunnel line. Data from [2]. Continuous lines represent data from the same BHs as the tested samples. NB the arrows indicate an example of mineralogy at a given depth.

Table 1: Index properties and initial conditions of the specimens. F stands for Folded, D for deionized, $\mathbf{S}$ for saline and I for Intact.

\begin{tabular}{llllllll}
\hline & FD1 & FS1 & FD2 & FD3 & FS3 & ID1 & IS1 \\
\hline $\mathrm{e}_{0}(-)$ & 1.02 & 1.00 & 1.00 & 0.97 & 1.00 & 0.96 & 0.95 \\
$\mathrm{~S}(-)$ & 1.01 & 1.01 & 1.00 & 0.98 & 1.00 & 0.99 & 0.99 \\
$\mathrm{w}(\%)$ & 36.6 & 36.2 & 35.6 & 34.1 & 35.7 & 33.9 & 34.0 \\
$\gamma\left(\mathrm{kN} / \mathrm{m}^{3}\right)$ & 18.6 & 18.7 & 18.7 & 18.7 & 18.6 & 18.8 & 18.8 \\
$\mathrm{I}_{\mathrm{p}}(\%)$ & 87.1 & 87.1 & 101.8 & 91.9 & 91.9 & 97.3 & 97.3 \\
\hline
\end{tabular}

\section{Methodology}

A series of oedometer tests were performed on rotary-cored samples of Røsnæs Clay, both Folded and Intact. The reconstituted tests were performed on trimmings 
remoulded at 1.5 times the liquid limit using synthetic water having the same chemical composition of the pore water in Røsnæs Clay from the Fehmarn Belt as determined by the Geological Survey of Denmark and Greenland (GEUS) [3]. This ensured consistency between the undisturbed and reconstituted samples.

A conventional incremental loading apparatus was used with a $10 \mathrm{~mm}$ thick and $70 \mathrm{~mm}$ diameter floating ring according to the Danish oedometer design. For all samples, the tests were repeated on two different specimens filling the water bath with deionized water (D) and saline synthetic water (S), to assess the effect of the pore water on compressibility and swelling. In particular, 2 tests on adjacent specimens were performed on Intact Røsnæs Clay (I), where one test was performed placing deionized water in the bath and one with saline water. Furthermore, 5 tests were performed on Folded Røsnæs Clay (F), where 3 used deionized water and 2 saline water. Tests with the same number were performed on adjacent specimens. For tests on Folded Røsnæs Clay, three swelling stages were performed during each test starting at different stress levels and unloading back to $\sigma_{\mathrm{v} 0}^{\prime}(\approx 400 \mathrm{kPa})$. The undisturbed specimens were quickly loaded to the in situ stress $\sigma_{\mathrm{v} 0}^{\prime}$ preventing any swell due to the water filled porous stones, and filling the cell only after reaching $\sigma_{\mathrm{v} 0}^{\prime}$.

\section{Results}

The Intrinsic Compression Lines obtained on reconstituted samples are showed in Fig.3. Their slope is $C_{c}=0.580$ in compression, regardless of the fluid filling the cell, but the ICL plots slightly higher for deionized water. This gap $(\Delta \mathrm{e}=0.040)$ is less than typical accuracy in determining void ratio in oedometer tests [4] and therefore for all practical purposes the ICL can be considered one. The ICL obtained for samples reconstituted with deionized water, which is not shown here for brevity, plots considerably higher instead $(\Delta \mathrm{e}=0.2)$.

The intrinsic swelling behavior is significantly different for deionized and saline water. This is because water leaving the specimen (i.e. during loading) does not alter the ion concentration of the pore fluid, while upon unloading the chemistry of the pore fluid entering the specimen determines the amount of swelling. In particular greater swelling is observed under saline conditions $\left(C_{s}=0.212\right)$, compared to deionized water $\left(C_{s}=0.150\right)$, although the repulsive force between particles reduces with increase in ions (i.e. salinity). As the repulsive force also depends on $\mathrm{pH}$ a possible explanation is an unbalance between the specimen and the external water $\mathrm{pH}$.

The compression curves of undisturbed Intact Røsnæs Clay (Fig.3a) remain parallel throughout compression and test ID1 plots only slightly above IS1. The curves cross the ICL showing positive effects of structure and start to yield at about $3 \mathrm{MPa}$, although they are still diverging from the ICL at the maximum stress applied (5 $\mathrm{MPa}$ ). The preconsolidation stress $\sigma_{\mathrm{p}}$, was estimated to 1.8MPa and 1.6MPa for ID1 
and IS1 respectively according to Casagrande's method The compression curves of undisturbed Folded Røsnæs Clay (Fig.3b) start from a rather narrow range, except for test FD1, having slightly higher $\mathrm{e}_{0}$ than ID1 and IS1. They all show a very gradual yielding and are approximately parallel to each other, but deform more than the Intact Røsnæs Clay at a given stress. Due to the lower maximum stress achieved, the compression curves are considerably less steep than the ICL and do not show any evidence of an imminent sharp yield point. However, they do show a linear trend in a semi-logarithmic plane after approximately $600-700 \mathrm{kPa}$. Based on this, some previous works (e.g. [5] and [6]) have established $\sigma^{\prime}{ }_{\mathrm{p}} \approx 350-1400 \mathrm{kPa}$, although the actual maximum stress under glaciers is estimated to be at least 5 - 8 MPa.
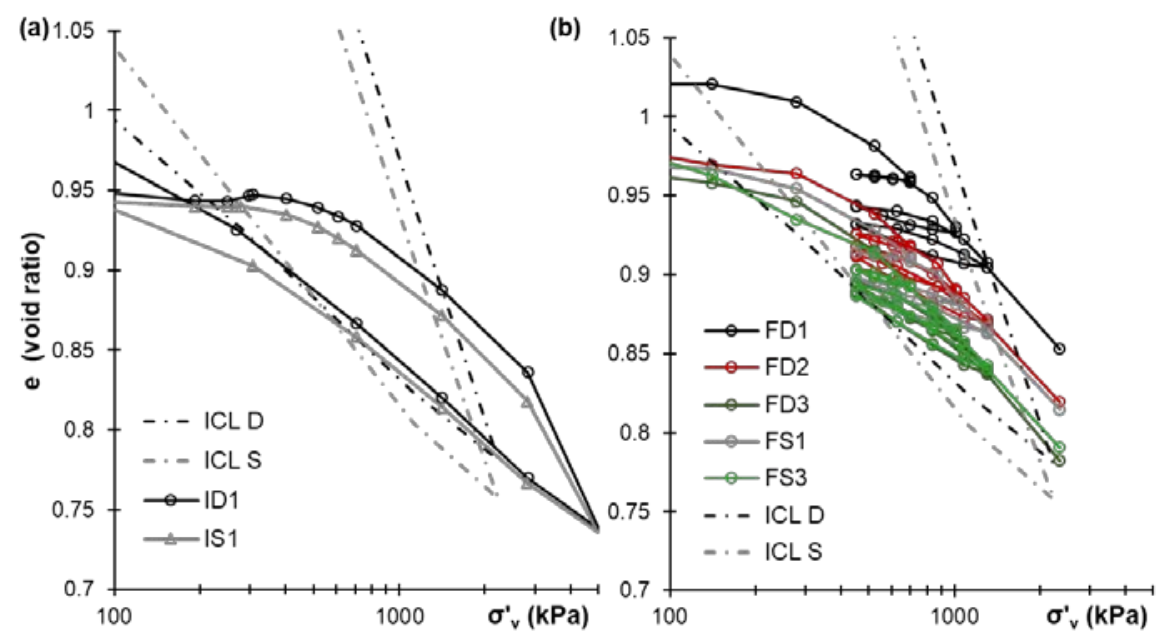

Fig.3: Compression tests on reconstituted and undisturbed Røsnæs Clay. (a) Intact Røsnæs Clay and (b) Folded Røsnæs Clay.

Grønbech et al. [7] observed an analogous behavior for the Søvind Marl, which is also a Danish Paleogene clay. Similarly to the tests on Intact Røsnæs Clay, a sharper yield point is observed at about $7 \mathrm{MPa}$ for this clay, which corresponds to the geological $\sigma_{\mathrm{p}}$. Grønbech et al. [7] attributed the initial gentler yielding to closing of fissures at the macro and meso scale. Gasparre \& Coop [8] also discussed the difficulty in identifying yield in stiff clays due to the high stresses required. In particular, they suggested swelling sensitivity $\left(S_{s}\right)$ as a good way to quantify destructuration, because it does not rely on there being a sharp yield point. Schmertmann [9] defined $S_{s}$ as the ratio between the swelling index $C_{s}$ for the reconstituted and undisturbed soil, where $\mathrm{C}_{\mathrm{s}}$ is calculated between the swelling pressure and approximately null stress, based on work by Bjerrum [10] on Lillebælt Clay, which incidentally is another Paleogene clay from Denmark. Schmertmann parameter relies 
on the fact that swelling curves tend to a horizontal asymptote when unloading below the swell pressure in samples preserving diagenetic bonding, resulting in $\mathrm{C}_{\mathrm{s}}$ lower than for the reconstituted samples (i.e. $S_{s}>1$ ). However, when undergoing large strains or weathering, the original micro structure is progressively lost and "full swelling" develops $\left(\mathrm{S}_{\mathrm{s}}=1\right)$.

Time consuming unloading and reloading cycles reaching progressively higher stress are then necessary to investigate the destructuration process. For this reason, this type of testing was limited to the Folded Røsnæs Clay. The starting points for swelling were selected below and above $\sigma_{p}$ as suggested by Rambøll Arup [5] (700 $\mathrm{kPa}, 1000 \mathrm{kPa}$ and $1300 \mathrm{kPa}$ ) and did not unload below $\sigma_{\mathrm{v} v}^{\prime}$ for time reason. However, the swelling pressure corresponds to approximately $1.5-2$ times $\sigma_{\mathrm{v} v}^{\prime}$.

The first unloading-reloading loop is generally subhorizontal (Fig.3) and for every loop the response is stiffer upon load reversal resulting in higher stiffness (M) and lower $\mathrm{C}_{\mathrm{s}}$. Fig.4a shows $\mathrm{M}$ during virgin loading and first reloading, where values from different unloading-reloading loops have been taken. During "virgin loading”, which however remains below the geological $\sigma_{\mathrm{p}}{ }^{\prime}, \mathrm{M}$ increases slightly with stress level. At a given stress, $M$ is larger if the specimen has already experienced the same stress before; however the second reloading does not influence substantially M. It is also observed that some points plot higher than the trend of the virgin loading; this is due to the proximity of the stress to a previously experienced. The most significant difference between virgin loading and reloading, however, is in proximity of the load reversal point. Nevertheless it is clear that higher stresses are required for reaching a linear variation of $\mathrm{M}$. Lodahl et al. [11] showed that friction loss between the ring and the specimen can result in $10-30 \%$ overestimate in stiffness for reconstituted samples having the same mineralogy.

(a)

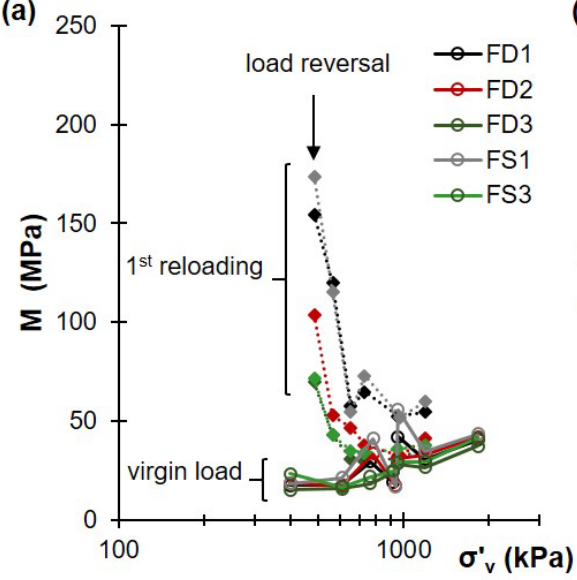

(b)

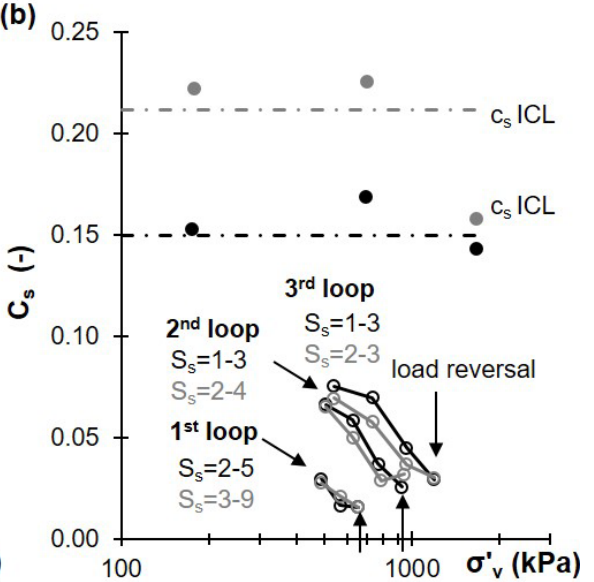

Fig.4: Destructuration as a result of cyclic loading on Folded Røsnæs Clay. (a) Change in oedometric modulus with subsequent loading and (b) changes in swelling index along different loops. 
The difference between tests with saline and deionized cell fluids is small and comparable to that of two specimens in a sample. Dedicated XRD analyses for each specimen are necessary to establish if the lack of a clear trend is due to significant changes in mineralogy at a sub-cm scale that might cloud the picture. Unlike $\mathrm{M}$ swelling is not directly linked to the number of times it has been subjected to the same stress on unloading, but $\mathrm{C}_{\mathrm{s}}$ increases with progressive cycles (Fig.4b) and also with reducing stress along one loop. For both Folded and Intact Røsnæs Clay undisturbed samples, $\mathrm{C}_{s}$ is slightly larger in the case of deionized water. Krogsbøll et al. [6] showed that unloading-reloading cycles starting from the same maximum stress and reaching progressively lower stress, follow the same swelling path.

(a)

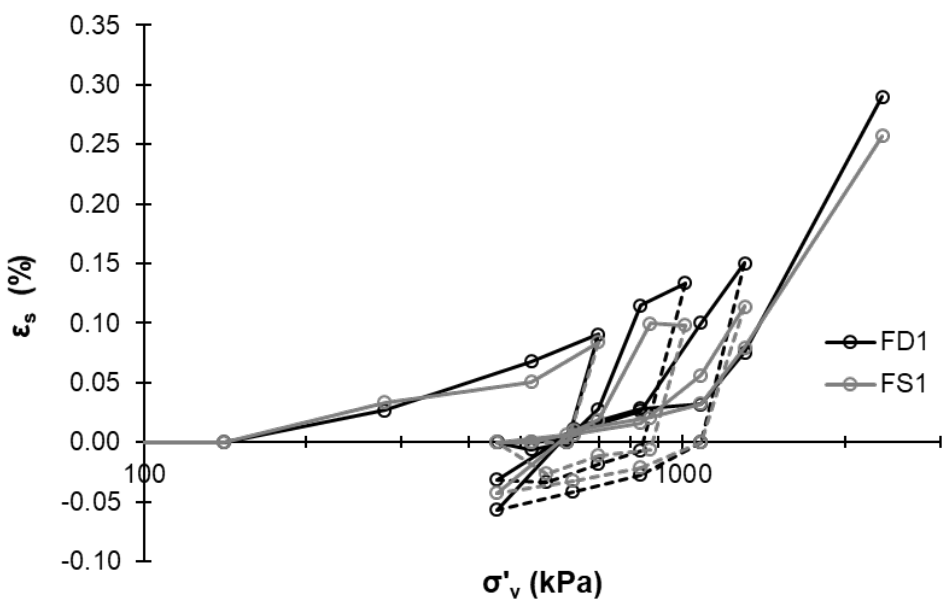

(b)

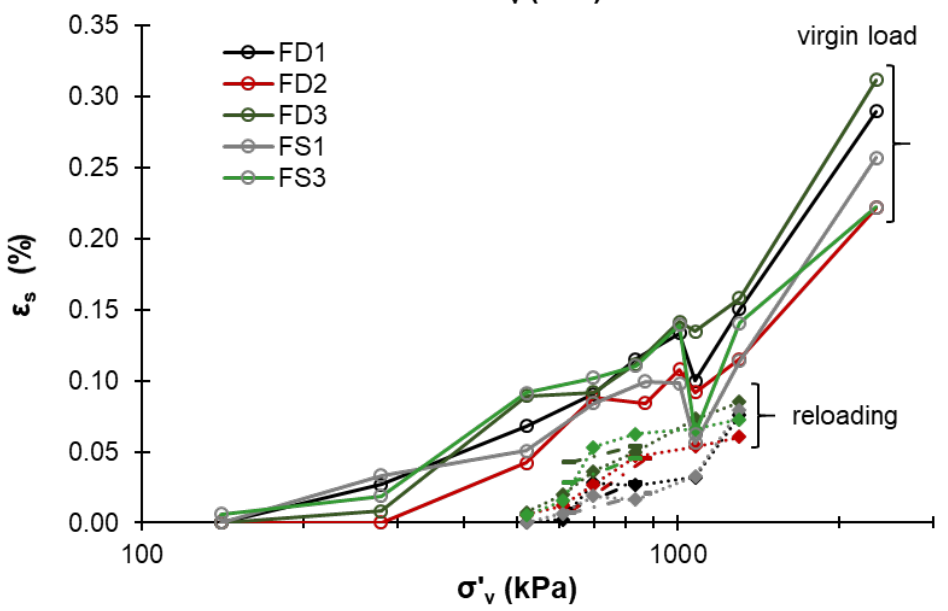

Fig.5: Rate of secondary compression for undisturbed Folded Røsnæs Clay as a result of cyclic loading. (a) Overall values for two example tests (b) "virgin loading" and subsequent reloading. 
Therefore, the distance from the reversal point does not determine the amount of swelling at a given stress. Progressive destructuration seems to be the cause for the behavior observed, based on the calculated $\mathrm{S}_{\mathrm{s}}$ values. These suggest that destructuration starts well before major yield and it is slightly smaller for deionized water filled cells. However, tests on Intact Røsnæs Clay (Fig.3a) show that even when unloading after the onset of major yielding, the swelling curves progressively diverge from the path followed by the reconstituted specimens tending to a horizontal asymptote at stresses below the swelling pressure, which is in contrast with [9].

Strains developed after the end of consolidation along the compression paths followed are showed in Fig.5a, where it is evident that typically there is no secondary compression at load reversal (Fig.5a). It is also observed that secondary compression in swelling is smaller than in "virgin loading", but increases with the amount of unloading cycles. Gasparre et al. [12] investigated the effects of creep rate on load reversal and showed that if the rate of secondary compression $\left(\varepsilon_{\mathrm{s}}\right)$ is comparable to the shearing rate during small-stiffness probes, the stiffness measured after load reversal is overestimated. This might explain further the larger stiffness measured upon load reversal (see Fig. 4a), although constant rate of strain tests should be carried out to investigate the phenomenon in detail. Finally, the data are presented similarly to Fig.5b, selecting $\varepsilon_{\mathrm{s}}$ according to the number of times a stress level has already been experienced. The values are approximately halved when reexperiencing a same load for a second time compared to "virgin loading", while afterwards $\varepsilon_{\mathrm{s}}$ remains similar. The stress dependency appears to be similarly reduced when moving from "virgin loading” to subsequent reloading.

\section{Conclusions}

This paper presented an initial set of one-dimensional compression tests on reconstituted and undisturbed Intact and Folded Røsnæs Clay, where the effects of salinity of the fluid filling the cell were investigated among others. The differences observed were comparable to those among specimens tested under the same environmental conditions, suggesting that the effect are rather small at least in compression. Clearer trends were observed in swelling. Large stresses are required to reach the geological preconsolidation stress and subsequent major yield. However, a considerable change in stiffness, secondary compression and swelling properties can be observed when comparing first loading to subsequent reloading cycles, even though the geological preconsolidation stress was not reached. Progressive destructuration linked to cyclic loading may be an explanation, however further elucidation of the swelling mechanisms and their dependency on cyclic loading is required to assess the destructuration through swelling sensitivity. 


\section{Acknowledgments}

The Authors would like to thank Ms Sine Maria Christensen, Mr Frederik Munck and Mr Andreas Randløv Kristensen for performing the tests on the undisturbed Intact Røsnæs Clay and the reconstituted samples.

\section{References}

[1] King, C. (1981). The stratigraphy of the London Basin and associated deposits. Tertiary Research Special Paper, Vol. 6, Backhuys, Rotterdam.

[2] Awadalkarim, A. (2014). Petrophysics of Palaeogene sediments. PhD thesis, Technical University of Denmark.

[3] Rambøll Arup (2014a). Appendix GDR 00.1-001-A Geological Interpretations of the 1996/2009/ 2010/2011/ 2012/2013 Borings. Femern Sund og Bælt. Prepared by Rambøll Arup Joint Venture. January 2014.

[4] Rocchi, I. and Coop, M.R. (2014). Experimental accuracy of the initial specific volume. ASTM Geotechnical Testing Journal, 37(1), 169-175.

[5] Rambøll Arup (2014d). Appendix GDR 00.1-001-D Geotechnical Properties for Clays of Palaeogene Origin. Femern Sund og Bælt. Prepared by Rambøll Arup Joint Venture. January 2014.

[6] Krogsbøll, A., Hededal, Ø. and Foged, N. (2012). Deformation properties of highly plastic fissured Paleogene clay - Lack of stress memory? Proceedings $16^{\text {th }}$ Nordic Geotechnical Meeting NGM 2012, May 9-12, Copenhagen, Denmark, Vol. 1, pp. 133-140.

[7] Grønbech, G.L., Ibsen, L. and Nielsen, B.N. (2015). Preconsolidation of Søvind Marl - a highly fissured Eocene Clay. ASTM Geotechnical Testing Journal, 38(4), 501-510.

[8] Gasparre, A. and Coop, M.R. (2008). Quantification of the effect of structure on the compression of a stiff clay. Canadian Geotechnical Journal, 45, 1324-1334.

[9] Schmertmann, J.H. (1969). Swell sensitivity. Géotechnique, 19(4), 530-533.

[10] Bjerrum, L. (1967). Progressive failure in slopes of overconsolidated plastic clay and clay shales. Third Terzaghi lecture. Journal of the Soil Mechanics and Foundations Division ASCE, 93(5), 3-49.

[11] Lodahl, M.R., Sørensen, K.K., Mortensen, N. and Trankjær, H. (2016). Oedometer tests with measurements of internal fricion between oedometer ring and clay specimen. Proceedings $17^{\text {th }}$ Nordic Geotechnical Meeting NGM 2016, May 25-28, Reykjavik, Iceland, Vol. 1, pp. 289-298.

[12] Gasparre, A., Hight, D.W., Coop, M.R. and Jardine, R.J. (2014). The laboratory measurement of the small-strain stiffness of stiff clays. Géotechnique, 64, pp. 942-953. 